Trakya Eğitim Dergisi

Cilt 10, Sayı 3

Eylül 2020, 776-794

Gelis Tarihi: 02.11.2019.

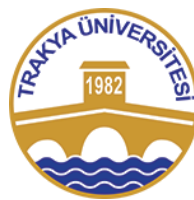

ISSN: 2630-6301

Doi: $10.24315 /$ tred.641782

Araştırma Makalesi/

Research Article
Trakya Journal of Education

Volume 10 , Issue 3

September 2020, 776-794

Yayına Kabul Tarihi:11.05.2020.

\title{
İki Dünya Kuramsal Çerçevesi’nin Mekanik Kavramlarını Gerçek Yaşamla İlişkilendirebilme ve Başarı Motivasyonu Üzerindeki Etkisi
}

\section{The Effect of Two Worlds Theoretical Framework on the Association of Mechanics Concepts with Daily Life and Achievement Motivation}

\section{Handan ÜREK ${ }^{1}$, Mustafa ÇORAMIK ${ }^{2}$, Erdoğan ÖZDEMİR ${ }^{3}$}

ÖZ: Bu çalışmada, İki Dünya Kuramsal Çerçevesi’nin, sınıf öğretmenliği öğrencilerinin bazı mekanik kavramlarını gerçek yaşam ile ilişkilendirebilmelerine ve başarı motivasyonlarına olan etkisinin incelenmesi amaçlanmıştır. $\mathrm{Bu}$ kapsamda, Türkiye'nin batısında bulunan bir devlet ünversitesinde öğrenim görmekte olan 53 sınıf öğretmenliği öğrencisi ile zayıf deneysel desende bir araştırma yürütülmüştür. Çalışmanın verileri; 'Mekanik Kavramlarını Gerçek Yaşam ile İlişkilendirebilme Formu' ve 'Başarı Odaklı Motivasyon Ölçeği' yardımıyla toplanmıştır. Araştırma süreci, iki haftalık öğretim ile birlikte veri toplama araçlarının ön-test ve son-test uygulamalarını içermektedir. Veri analizinde hem nitel hem de nicel yöntemlerden yararlanılmıştır. Çalışma sonuçlarına göre yapılan öğretimin, öğrencilerin mekanik kavramlarını gerçek yaşamla ilişkilendirebilmelerine olumlu etkilerde bulunduğu ortaya çıkmıştır. Ayrıca çalışma sonucunda öğrencilerin başarı motivasyonlarının istatistiksel açıdan anlamlı bir artış gösterdiği belirlenmiştir. İki Dünya Kuramsal Çerçevesi'nin, sınıf öğretmenliği öğrencileri için diğer fizik dersi konularının öğretiminde de kullanılabileceği düşünülmektedir.

Anahtar sözcükler: İki Dünya Kuramsal Çerçevesi, fizik, başarı motivasyonu.

\begin{abstract}
In this study, it was aimed to investigate the effect of Two Worlds Theoretical Framework on classroom teacher students' association of several mechanics concepts with daily life and achievement motivation. For this reason a weak experimental study was conducted with the attendance of 53 classroom teacher students studying in a state university located in the western part of Turkey. Data were collected with the help of 'The Form of Associating Mechanics Concepts with Daily Life' and 'Achievement Focused Motivation Scale'. The research involved a two-week teaching process and the application of data gathering instruments as pre and post-test in the previous and following weeks of the teaching. Both qualitative and quantitaive methods were utilized in data analysis. According to the results, it was determined that the teaching contributed students' association of the mechanics concepts with daily life. Also, it was found that the teaching increased students' achievement motivation in a statistically significant manner. It is thought that Two Worlds Theoretical Framework might be utilized in the teaching of other physics subjects for classroom teacher students.
\end{abstract}

Keywords: Two Worlds Theoretical Framework, physics, achievement motivation.

Bu makaleye atıf vermek için:

Ürek, H., Çoramık, M. \& Özdemir, E. (2020). İki dünya kuramsal çerçevesi’nin mekanik kavramlarını gerçek yaşamla ilişkilendirebilme ve başarı motivasyonu üzerindeki etkisi. Trakya Eğitim Dergisi, 10(3), 776-794

Cite this article as:

Ürek, H., Çoramık, M. \& Özdemir, E. (2020). The effect of two worlds theoretical framework on the association of mechanics concepts with daily life and achievement motivation. Journal of Trakya Education, 10(3), 776-794

\section{Introduction}

\section{EXTENDED ABSTRACT}

The purpose of the present study is to determine the effect of Two Worlds Theoretical Framework on classroom teacher students' association of several mechanics concepts with daily life and their achievement motivation. The study is thought to be significant since it introduces the application of a less-known approach with a practical concern of different physics concepts which are determined to be problematic to learn and also it focuses on students' willing to succeed.

\footnotetext{
1 Araş. Gör. Dr., Balıkesir Üniversitesi, Necatibey Eğitim Fakültesi, Matematik ve Fen Bilimleri Eğitimi Bölümü, handanurek@balikesir.edu.tr, ORCID: 0000-0002-3593-8547

2 Araş. Gör. Dr., Balıkesir Üniversitesi, Necatibey Eğitim Fakültesi, Matematik ve Fen Bilimleri Eğitimi Bölümü, mustafacoramik@balikesir.edu.tr, ORCID: 0000-0002-3225-633X

3 Dr. Öğr. Üyesi, Sivas Cumhuriyet Üniversitesi, Sağlık Hizmetleri Meslek Yüksekokulu, Optisyenlik Programı, erdoganozdemir@cumhuriyet.edu.tr, ORCID:0000-0001-7943-8002
} 


\section{Method}

A weak experimental study (one group pre-test - post-test design) was implemented with the attendance of 53 classroom teacher students studying in a state university in the western part of Turkey. The study was conducted in terms of the physics course given in the third semester of the classroom teaching program. The research involved a two-week teaching process two hours a week and the application of data gathering instruments as pre and post-test in the previous and following weeks of the teaching. The subject of motion in one dimension was taught with the help of Two Worlds Theoretical Framework. Data were obtained via (i) The Form of Associating Mechanics Concepts with Daily Life developed by the researchers and (ii) Achievement Focused Motivation Scale developed by Semerci (2010). The Form of Associating Mechanics Concepts with Daily Life examined five concepts: position, displacement, average velocity, average speed and acceleration. Achievement Focused Motivation Scale was Likert 5-type and involved 35 items. 34 of the items were positive statements whereas one of the items was a negative statement. Both qualitative and quantitative methods were utilized for the data analysis. Data obtained from the Form of Associating Mechanics Concepts with Daily Life were analyzed under two themes: Daily Life related Examples and No Daily Life related Examples. In addition to the presentation of the analysis results descriptively, statistical comparisons were made between pre and post-test results related to daily life associations of the participants with the help of Wilcoxon signed rank tests. Data obtained from Achievement Focused Motivation Scale were scored from ' 1 ' to ' 5 ' points and the final scores were calculated for pre and post-test applications. Thus, a statistical comparison was also made between pre and post-test results of the participants' achievement focused motivations with the help of paired sample t-test.

\section{Findings}

According to the findings of the study, the students were found to provide more daily life related examples in the post-test. Also, students' examples were found to indicate a statistically significant improvement from pre to post-test except the concept of average velocity. In the pre-test, the students were found to state more examples which were not related to the daily life applications. This kind of answers could be in the form of correct definitions, indefinite or irrelevant responses, incorrect responses or could provide no answer. Besides, students' achievement motivation was found to increase in a statistically significant manner from pre $(\bar{X}=133.93)$ to post-test $(\bar{X}=142.09), \mathrm{t}(52)=4.504, \mathrm{p}<.05$.

\section{Discussion and Conclusion}

To conclude, Two Worlds Theoretical Framework was found to improve students' association of several mechanics concepts with daily life and increased their achievement motivation. On the other hand, a number of incorrect responses were determined especially in the pre-test part of the study. Several incorrect responses were found to be consisted with the literature which reports misconceptions of the university level students at this respect. Using the concept of average velocity without vectors and defining acceleration as the distance taken per unit time during speeding up of a car might be mentioned at this respect. Also mentioning 'bus' in terms of the concept of displacement and 'Formula 1 car' for the concept of average velocity indicated indefinite responses.

In the light of the study findings, it is realized that teaching the concepts of average speed and average velocity requires extra techniques or materials to make students differentiate them when post-test results are considered. Also, teaching the concept of vector might be addressed in a detailed manner in the future studies when the incorrect responses are considered about the concepts of position, displacement, average velocity and acceleration. Finally, it might be asserted that Two Worlds Theoretical Framework might be utilized in teaching of other physics subjects for classroom teacher students. This approach is thought to be efficient when the time interval is limited for the teaching process. Finally, as can be seen in the results of the present study, making relevant connections with real world enhances students' learning by fostering scientific conceptions and motivation. 


\section{GíRiş}

Evrenin temel prensipleri ile ilgilenen fizik; az sayıda temel kavram, denklem ve varsayım ile çevreye olan bakış açısını değiştirir ve genişletir (Serway \& Beichner, 2002). Fizik konuları beş temel alana bölünebilir. Bunlar; klasik mekanik, rölativite teorisi, termodinamik, elektromanyetizma ve kuantum mekaniğidir. Bunlardan klasik mekanik, ışık hızından çok küçük hızlarda hareket eden ve atomlara göre çok büyük olan cisimlerin hareketi ile ilgilidir. Bir ders olarak ele alındığında, fizik dersi konularının önemli bir kısmını mekanik konularının oluşturduğu görülmektedir. Başka bir şekilde tanımlamak gerekirse; mekanik, cisimlerin hareketi ile kuvvet ve enerji ilişkisini inceleyen fiziğin bir alt dalıdır (Giancoli, 1998). Dolayısıyla fizik dersinde; kuvvet, hız, sürat, ivme, hareket, yer değiştirme, konum, momentum, denge gibi kavramlar, mekanik konuları kapsamında öğretilmektedir.

Yapılan çalışmalar sonucunda, farklı öğrenim düzeylerindeki öğrencilerin mekanik kavramlarını anlamada problemler yaşadığı gösterilmektedir (Atabek-Yiğit, Yılmazlar \& Çetin, 2016; Atasoy, Küçük \& Akdeniz, 2011; Ateş, 2008; Bayraktar, 2009; Eryılmaz, 2002; Fadaei \& Mora, 2015; Stylos, Evangelakis \& Kotsis, 2008; Tebabal \& Kahssay, 2011; Tural, 2017; Türker, 2005). Bu çalışmaların çoğunlukla lise öğrencileri (Eryılmaz, 2002; Fadaei \& Mora, 2015; Jones, 1983; Tebabal \& Kahssay, 2011; Tural, 2017; Türker, 2005) ve öğretmen adayları (Atabek-Yiğit, Y1lmazlar \& Çetin, 2016; Atasoy, Küçük \& Akdeniz, 2011; Ateş, 2008; Bayraktar, 2009; Tural, 2017) ile gerçekleştirildiği görülmektedir. Öğretmen adayları ile gerçekleştirilen çalışmaların ise çoğunlukla fen bilgisi öğretmen adayları ile gerçekleştirildiği belirlenirken (Atasoy, Küçük \& Akdeniz, 2011; Ateş, 2008; Bayraktar, 2009) sınıf ögretmeni adayları ile bu kapsamda gerçekleştirilmiş çalışmaların sınırlı olduğu tespit edilmiştir (Atabek-Yiğit, Yılmazlar \& Çetin, 2016).

Farklı sınıf seviyelerindeki öğrenciler ile gerçekleştirilen çalışmalar sonucunda öğrencilerin mekanik kavramları ile ilgili kavram yanılgıları taşıdıkları belirlenmiştir. Bunlardan, üniversite seviyesindeki öğrenciler ile yapılan çalışmalarda tespit edilen bazı kavram yanılgıları şöyledir:

(i) Hareketi, en büyük kuvvet belirler (Bani-Salameh, 2017; Bayraktar, 2009).

(ii) Bir cismin hareketini başlatan kuvvet, hareket boyunca cisim üzerinde etkili olmaya devam eder (Atasoy, Küçük \& Akdeniz, 2011).

(iii) Ağır objeler daha hızlı düşer (Anggoro, Widodo \& Suhandi, 2017; Bani-Salameh, 2017; Bayraktar, 2009; Poutot \& Blandin, 2015; Şimşek, 2018).

(iv) Hareket yoksa kuvvet de yoktur (Bani-Salameh, 2017; Bayraktar, 2009; Budak, 2011; Poutot \& Blandin, 2015).

(v) Sağa doğru sabit hızla hareket etmekte olan bir arabaya uygulanan net kuvvet de sağa doğrudur (Jimoyiannis \& Komis, 2003; Poutot \& Blandin, 2015; Stylos, Evangelakis \& Kotsis, 2008).

$\mathrm{Bu}$ konuyla ilgili lise düzeyindeki öğrencilerde tespit edilen kavram yanılgıları ise şöyle siralanabilir:

(i) Hareketi, en büyük kuvvet belirler (Fadaei \& Mora, 2015; Türker, 2005).

(ii) İvme, artan bir kuvvet oluşumuna neden olur (Fadaei \& Mora, 2015).

(iii) Ağır objeler daha hızlı düşer (Fadaei \& Mora, 2015).

(iv) Hareket yoksa kuvvet de yoktur (Eryllmaz \& Tat1, 2000; Fadaei \& Mora, 2015).

(v) Hareket, hareket yönünde bir kuvvetin olduğunu gösterir (Eryılmaz \& Tatlı, 2000; Jimoyiannis \& Komis, 2003).

(vi) Yer değiştirmenin sıfır metre olması, hiç uzaklık kat edilmediğini gösterir (Motlhabane, 2016).

Yukarıda bahsedilen kavram yanılgıları incelendiğinde bazı kavram yanılgılarının (i, iii, iv) hem lise hem de üniversite seviyesindeki öğrencilerde bulunduğu görülmektedir. Bu durum da bazı kavram yanılgılarının sınıf düzeyinden bağımsız olarak öğrencilerde devam ettiğini ve değişime karşı dirençli olduklarını göstermektedir. Bu kavram yanılgılarının yanında, öğrencilerin hız ve ivme (Bayraktar, 2009; Fadaei \& Mora, 2015; Jones, 1983; Poutot \& Blandin, 2015); hiz ve sürat (Jones, 1983); konum ve hız (Fadaei \& Mora, 2015; Poutot \& Blandin, 2015; Trowbridge \& McDermott, 1980) kavramlarını ayırt edemedikleri belirlenmiştir. Öğrencilerin kuvvet kavramına yönelik anlamalarının de net olmadığı belirtilmektedir (Anggoro, Widodo \& Suhandi, 2017). Bu çalışmalardan anlaşılacağ 1 üzere, 
öğrencilerin mekanik konularındaki kavramsal anlamalarının iyileştirilmesine yönelik araştırmalara ihtiyaç duyulmaktadır.

Mekanik konularını öğrenmedeki problemlerin sebeplerinden birisinin, öğrenilen kavramların gerçek yaşam ile ilişkilendirilememesi olduğu söylenebilir. Nitekim üniversite öğrencileri ile yapılan araştırmalar sonucunda fizik, kimya ya da biyoloji ile ilgili teorik bilgilerin günlük yaşam ile yeterince bağdaştırılamadığı görülmektedir (Balkan Kıyıcı \& Aydoğdu, 2011; Gutwill-Wise, 2001; Özmen, 2003; Soudani, Sivade, Cros \& Médimagh, 2000; Yadigaroğlu \& Demircioğlu, 2012; Y1ldırım \& Birinci Konur, 2014).

Fizik dersinin sınıf öğretmenliği lisans programındaki yeri incelendiğinde; 1998 yılında uygulamaya konulan programda bu dersin genel fizik adı altında, ikinci sınıf düzeyinde birinci yarıyılda haftada 3 ders saati halinde öğrencilere verildiği görülmektedir (YÖK, 1998). 2007 yılında yapılan program değişikliği sonucunda, dersin adının ve verildiği dönemin aynı kaldığı görülürken haftalık ders saatinin ikiye inmesi dikkat çekmektedir (YÖK, 2007). Yapılan son değişikliğe göre ise 2018-2019 akademik yılından itibaren birinci sinıflarda uygulamaya konulan yeni programda bu derse yer verilmemiştir (YÖK, 2018). Bahsedilen son program değişikliğinden önce, ikinci sınıf düzeyinde haftada iki ders saati şeklinde verilen bu dersin içeriğinin yoğunluğu dikkati çekmektedir. Bu içeriğin; mekanik, optik, 1sı-sıcaklık, elektrik, 1şık ve ses konuları gibi geniş bir alana dağıldığı fakat sınırlı bir sürede öğretilmesinin hedeflendiği görülmektedir (YÖK, 2007).

Uygulamaya konulan 2018-2019 sınıf öğretmenliği lisans programında genel fizik dersi olmamasına rağmen programda fen bilimleri laboratuvar uygulamaları isimli bir dersin yer aldığı görülmektedir (YÖK, 2018). Bu ders kapsamında, fen bilimleri dersini oluşturan bazı fizik, kimya ve biyoloji kavramlarına ilişkin basit deneyler laboratuvar ortamında uygulamalı olarak gerçekleştirilmektedir. Böylece öğretmen adaylarına fen kavramlarıyla ilgili deney yapabilme becerisi kazandırılması hedeflenmektedir. İlkokul fen bilimleri dersi programı incelendiğinde; kuvvet ve hareket kavramlarının üçüncü ve dördüncü sınıf düzeylerinde öğrencilere öğretilmesi hedeflendiği görülmektedir (MEB, 2018). Ayrıca, bahsedilen sınıf öğretmenliği lisans programında 'ilkokulda temel fen bilimleri' ve 'fen öğretimi' isimli zorunlu dersler de yer almaktadır. Dolayısıyla, sınıf öğretmeni adaylarının fen öğretimi yapabilmeleri için bazı fizik ve mekanik kavramlarını zihinlerinde iyi yapılandırmaları, bir gereklilik olarak ortaya çıkmaktadır.

Sınıf öğretmenliği öğrencileri için 2018-2019 akademik yılına kadar uygulanan lisans programı dikkate alındığında bu öğrencilerin fizik dersi ve mekanik konularını anlama zorluğunun ortaya çıkmasında başlıca iki durumun etkili olduğu söylenebilir (Yavuz \& Fide, 2010):

(i) Sınıf öğretmenliği programında fizik dersi için haftalık iki ders saati ayrıldığı görülmektedir. Bu süre öğretim açısından oldukça sınırlıdır.

(ii) Sınıf öğretmenliği programı eşit ağırlıklı puan türünde öğrenci kabul etmektedir. Bu da öğrencilerin daha düşük fen bilimleri puanları ile programa yerleşebilmelerine imkan vermekte; dolayısıyla öğrencilerin hazırbulunuşluk düzeyi fen konularında düşük kalmaktadır.

Mekanik konularının öğrencilere daha etkili bir şekilde öğretimini gerçekleştirmek için çalışma yaprakları (Atasoy, Küçük \& Akdeniz, 2011), kavramsal ödevler ve kavramsal değişim tartışmaları (Eryılmaz, 2002), kuantum öğrenme modeli (Karamustafaoğlu, 2018) gibi farklı yöntem ve tekniklerden yararlanıldığı görülmektedir. Bu yöntem ve tekniklerden olumlu sonuçlar alınmasında, öğrenciler ve konunun öğretimi açısından en uygun olanların seçilmesi önem taşımaktadır. Yavuz ve Fide (2010) ise yaptıkları araştırmada, İki Dünya Kuramsal Çerçevesi'nin sınıf öğretmenliği öğrencileri için fizik dersinin öğretiminde kullanılabileceğine dikkat çekmektedirler.

İki Dünya Kuramsal Çerçevesi, fizik öğretiminde modellemenin önemli bir rol oynadığını varsayarak fiziksel dünyadaki olay ve objeleri (obje/olaylar dünyasi), teori ve modeller ile (model/kuramlar dünyası) ilişkilendirerek açıklamayı amaçlar (Ruthven, Laborde, Leach \& Tiberghien, 2009). Obje ve olaylar dünyası, gözlemleri ve ölçümleri içerirken model ve kuramlar dünyası ise gözlemlenen olayların bilimsel açıklamalarını içerir (Rodríguez-Velázquez, 2013). Şekil 1'de, İki Dünya Kuramsal Çerçevesi görsel olarak ifade edilmektedir (Ruthven ve diğerleri, 2009). 


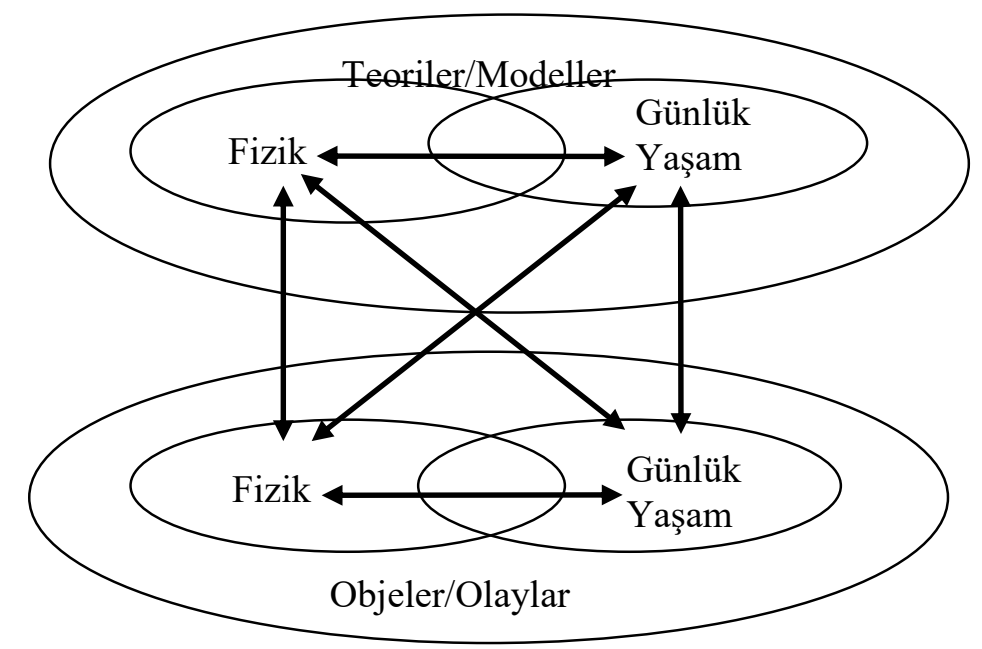

Şekil 1. İki dünya kuramsal çerçevesinin fizik öğretiminde kullanımı

Kaynak: Ruthven, K., Laborde, C., Leach, J., \& Tiberghien, A. (2009). Design tools in didactical research: instrumenting the epistemological and cognitive aspects of the design of teaching sequences. Educational Researcher, 38(5), 329-342.

Şekil 1'den de anlaşılacağı üzere İki Dünya Kuramsal Çerçevesi'nde, model ve kuramlar dünyası, modelleme yolu ile obje ve olaylar dünyasına bağlanır. Bilgiyi, obje/olaylar dünyası ve model/kuramlar dünyası halinde ayrıştıran bu yöntem, öğrencilerin fiziği öğrenmede yaşadığı zorlukların yorumlanmasına imkan verir (Tiberghien, 2000). Ayrıca, gerçek yaşamdan seçilen bağlamların, öğrencilerin motivasyonları ve sosyal duyarlılıkları üzerinde de olumlu etkiler yaratacağı belirtilmektedir (Whitelegg \& Parry, 1999). Bu yaklaşım, mekanik konularının öğretimi açısından ele alındığında ise kavramları uygulama alanlarıyla eşleştirerek kavramların gerçek yaşamdaki yerini öğrenciler için somut bir hale getirebileceği ve anlamayı kolaylaştıracağı söylenebilir. Bahsedilen nedenlerle, bu çalışmada bazı mekanik kavramlarının İki Dünya Kuramsal Çerçevesi ile öğretimine odaklanılmıştır.

Literatür incelendiğinde, İki Dünya Kuramsal Çerçevesi'ni kullanan araştırmaların sınırlı olması dikkati çekmektedir (Rodríguez-Velázquez, 2013; Yavuz \& Fide, 2010). Rodríguez-Velázquez (2013) elektrokimya konusunun öğretiminde ve öğrenilmesinde yaşanan sorunlar nedeniyle yaptığı araştırmada bu konunun üniversite seviyesindeki öğretiminde İki Dünya Kuramsal Çerçevesi'nin kullanımına odaklanmıştır. Araştırmaya, iki farklı ögretim üyesi ve bu öğretim üyeleri tarafından verilen genel kimya dersini alan olan üniversite öğrencileri dahil edilmiştir. Araştırma sonucunda, İki Dünya Kuramsal Çerçevesi'nin seçilen elektrokimya konusunun öğrencilere aktarımını daha açık bir hale getirdiği ortaya çıkmıştır. Ayrıca, yapılan öğretimin öğretim üyelerinin uzmanlığından etkilendiği de bulunmuştur. Buna göre derslerde kurulan bağlantılar ve ders kitapları kullanımı, öğretim üyeleri arasında farklılık göstermektedir. Bir başka çalışmada, Yavuz ve Fide (2010) sınıf öğretmeni adayları için genel fizik dersinin öğretiminde İki Dünya Kuramsal Çerçevesi’nin kullanımını araştırmışlardır. $\mathrm{Bu}$ çalışma kapsamında araştırmacılar bir dönem boyunca genel fizik dersini ele alınan yaklaşıma göre yeniden yapılandırmışlardır. Çalışmanın başlangıcında katılımcıların çoğunluğunun fizik dersi hakkında olumsuz düşüncelere sahip oldukları belirlenirken araştırma sonunda öğretmen adaylarının fizik dersi hakkındaki önyargılarının kaybolduğu ve fizik dersini günlük yaşam ile anlamlandırabildikleri bulunmuştur. Ülkemizde, öğrencilerin fizik dersini günlük yaşam ile ilişkilendirebilmeleri için öğretim programı düzeyinde de çalışmalar yapıldığı görülmektedir. Nitekim ilköğretim düzeyinde yapılan değişikliklere paralel olarak 2007 yılında fizik dersi öğretim programında da değişikliğe gidilmiş ve bu program üzerinde 2013 yılında yapılan düzenlemeler ile yaşam temelli fizik yaklaşımı benimsenmiştir (Ayvacı, Bebek, Özbek \& Yamak, 2015). Son güncelleme sonucunda 
2018 y1lında uygulamaya konulan fizik öğretim programının temel amaçları ve felsefesi kapsamında; bilginin yaşamda kullanılabilmesi, kazanımlar ile yaşam arasında ilişki kurulabilmesi üzerinde durulmaktadır (MEB, 2018).

Öğrenmeyi ve başarıyı etkileyen önemli etmenlerden birisi, motivasyondur (Aluçdibi, 2010). Watters ve Ginns'e (2000) göre motivasyon, farklı eylemlerdeki davranışı ve çabayı açıklamaya çalışan karmaşık bir psikolojik yapıdır. Motivasyon; öğrencilerin öğrenmelerini, ders çalışmalarını, okulda başarılı olmalarını sağlayan enerji ve güdü olup çok boyutludur (Martin, 2001). Araştırmalar sonucunda, öğrencilerin, bilişsel ve duyuşsal gereksinimlerine hitap eden fikirleri öğrenmeye karşı daha motive oldukları belirtilmektedir (Butler, 2009). Literatürde, Maslow'un İhtiyaçlar Hiyerarşisi Kuramı, Alderfer'in Varlık, İlgililik ve Gelişme Kuramı, Herzberg'in Çift Faktör Kuramı, Mc Clelland'in Başarı Güdüsü Kuramı gibi motivasyon ile ilgili farklı kuramlar bulunmaktadır (Erdem, 1997). Bu kuramlarda motivasyona değişik bakış açıları ile açıklamalar getirilmektedir. Bu kapsamda üzerinde durulan bir kavram da başarı motivasyonudur. Nitekim öğrencilerin başarı hedefleri, öğrenme sürecinin çeşitli aşamalarında etkili olabilmektedir (Rosa \& Bernardo, 2013). Bir öğrencinin standardını belirlediği hedefine ulaşmak için zaman ve enerjisini ayarlaması, başarı motivasyonu olarak tanımlanmaktadır (Ülgen, 1994). Kavramlar ile günlük yaşam arasında ilişki kurulmasının başarı motivasyonunu olumlu etkileyeceği ve öğretmen adaylarının öğrenme süreci üzerinde önemli bir etkiye sahip olacağ düşünülmektedir.

Bu çalışmanın amacı, İki Dünya Kuramsal Çerçevesi’nin, sınıf öğretmenliği öğrencilerinin bazı mekanik kavramlarını gerçek yaşam ile ilişkilendirebilmeleri ve başarı motivasyonları üzerindeki etkisinin incelenmesidir.

Sınıf öğretmenleri, küçük yaştaki öğrencilere gelecekteki konulara temel olacak kavramların öğretimini gerçekleştirmektedir (Kikas, 2004). Bu nedenle sınıf öğretmenleri, eğitim-öğretim sürecinde önemli bir göreve sahiptir. Bu yaştaki öğrenciler için fen dersi kapsamında ele alınan fizik konularının öğretiminde, kavramların gerçek yaşamdaki yerinin ön plana çıkarılması çok önemlidir. Böylece, fen dersi öğrencilerin gözünde anlamlı hale gelebilir ve öğrencilerin derse karşı güdülenmeleri sağlanabilir. Her ne kadar sınıf öğretmenliği lisans programında yapılan son değişiklik ile fizik dersi, program dışı kalsa da fen bilimleri dersi konularının bir kısmı fizik ve mekanik kavramları ile ilgilidir. Sınıf öğretmenliği lisans programında devam eden fen bilimlerinde laboratuar uygulamaları dersinde de bu kavramlar ele alınmaktadır. Dolayısıyla, mekanik kavramlarının öğretiminin önemli olduğu düşünülmekte ve öğretmen adaylarının mekanik kavramlarının önemini anlamasının, onların başarı motivasyonlarına olumlu yansıması beklenmektedir.

Yukarıda bahsedilen nedenlerle, bu çalışmanın, sınıf öğretmeni adayları için fizik dersinin öğretiminin nasıl daha etkili bir şekilde yapılabileceğini ortaya koyması açısından önem taşıdığı düşünülmektedir. Bu çalışmada uygulanan yaklaşımın, mekanik konuları kapsamında bir örnek sunarak sınıf öğretmeni adaylarının fizik eğitimi açısından alana katkılarda bulunması beklenmektedir. Ayrıca, uygulanan yaklaşımın, öğretimi sınırlı ders saati içinde gerçekleştirilmek zorunda olan diğer fizik konuları açısından da örnek teşkil etmesi beklenmektedir.

\section{YÖNTEM}

\section{Araștırma Modeli}

$\mathrm{Bu}$ çalışma, zayıf deneysel desenlerden tek grup ön-test-son-test desenindedir. $\mathrm{Bu}$ desen, araştırmada gerçekleştirilen deneysel işlemin etkisinin, tek bir grup üzerinde aynı veri toplama araçları kullanılarak uygulama öncesinde ve sonrasında yapılan ölçümler arasındaki farkın anlamlılığının test edilmesine dayanır (Büyüköztürk, Kılıç Çakmak, Akgün, Karadeniz \& Demirel, 2010). Gerçekleştirilen çalışmada da üniversite ögrencilerinden oluşan tek bir grup vardır. Çalışma kapsamında bu grup üzerinde yapılan öğretimin, öğrencilerin araştırmaya konu edilen bazı mekanik kavramları ile ilgili günlük yaşamdan örnekler verebilmeleri ve başarı motivasyonları üzerindeki etkisi incelenmektedir. $\mathrm{Bu}$ etki de çalışma grubunun, çalışma başlangıcındaki ve sonundaki durumlarının aynı veri toplama araçlarının kullanılması yardımıyla ölçülüp karşılaştırılması ile belirlenmektedir. Çalışmada hem nitel hem de nicel yaklaşımlardan yararlanılmıştır. Öğretmen adaylarının mekanik kavramlarını gerçek yaşamla ilişkilendirebilmesinin incelenmesinde nitel ve nicel yaklaşımlar; başarı motivasyonlarının incelenmesinde ise nicel yaklaşımlar kullanılmıştır. Kullanılan nicel yaklaşımlar yardımıyla, gerçekleştirilen öğretimin etkisinin anlamlılığı incelenmiştir. 
$\mathrm{Bu}$ çalışmada olduğu gibi zayıf deneysel desenlerden tek grup ön-test-son-test deseninde, iç geçerliliği tehdit eden faktörlerin kontrol edilememesi ve seçkisizliğin olmaması, araştırma deseninin olumsuzları arasında gösterilebilir (Büyüköztürk ve diğerleri, 2010). Bu olumsuzluğun üstesinden gelmek için bir kontrol grubunun kullanılması, çalışmada gerçekleştirilen öğretimin etkisini daha açık bir şekilde ifade etmeye yardımcı olabilir. Bu durum, çalışmanın bir sınırlılığı olarak ortaya çıkmaktadır.

\section{Çalışma Grubu}

Çalışma, Türkiye'nin batısında bulunan bir devlet üniversitesinin eğitim fakültesinde, sınıf öğretmenliği programında öğrenim görmekte olan 53 öğrenci ile gerçekleştirilmiştir. Katılımcıların 18'i erkek, 35'i ise kadın öğrencilerden oluşmaktadır. Çalışma, 2018-2019 akademik yılının güz yarıyılında gerçekleştirilmiştir. Çalışmaya katılan öğrencilerin tamamı, söz edilen programda ikinci sınıf düzeyinde verilen genel fizik dersini almaktadır. Dolayısıyla çalışma grubunu oluşturan öğrenciler, daha önce bahsedildiği üzere 2018-2019 akademik yılında birinci sınıflardan itibaren uygulanmaya başlanan yeni programa tabi değildirler.

Çalışmanın örneklemi, araştırmacılara zaman ve uygulama açısından kolaylık sağlaması nedeniyle kolay ulaşılabilir örnekleme yaklaşımı ile oluşturulmuştur (Yıldırım \& Şimşek, 2008). Ancak diğer örnekleme yaklaşımları ile karşılaştırıldığında, araştırma sonuçlarının güvenirliği, genellenebilirliği ve kullanılabilirliğinin daha sınırlı olması, bu yaklaşımın olumsuzlukları arasında sayılabilir (Büyüköztürk ve diğerleri, 2010; Yıldırım \& Şimşek, 2008). Bu nedenle, yapılan çalışmada elde edilen sonuçlar, çalışmaya katılan bir grup üniversite öğrencisi ile sınırlıdır.

\section{Veri Toplama Araçları}

Çalıșmanın verileri, iki veri toplama aracı yardımıyla toplanmıștır. Bunlar; (i) Mekanik Kavramlarını Gerçek Yaşam ile İlişkilendirebilme Formu (MKGYİF) (ii) Başarı Odaklı Motivasyon (BOM) Ölçeği'dir.

MKGYİ, araştırmada incelenen kavramların öğrenciler tarafından gerçek yaşam uygulamalarıyla nasıl örneklendirildiğini ortaya çıkarmak amacıyla, araştırmacılar tarafından geliştirilmiștir. Bu kapsamda, ilk olarak sınıf öğretmenliği lisans programının genel fizik dersi programı (YÖK, 2007) incelenmiştir. Bu inceleme sonucunda genel fizik dersi programında yer alan ilk konunun mekanik (hareket, hız, ivme) olduğu görülmüştür. Böylece programın, tek boyutta hareket konusu ile başladığı belirlenmiş ve bu kapsamda hedef kavramların bir listesi çıkarılmıştır. Bu kavramlar; kuvvet, etki-tepki, denge, konum, yer değiştirme, hareket, sürtünme, hız, sürat ve ivme şeklinde listelenmiştir. $\mathrm{Bu}$ çalışmaya, listelenen kavramlardan beşi dahil edilmiştir. Çalışmaya dahil edilen kavramlar, sınıf öğretmenliği öğrencileri için genel fizik dersinin öğretiminde kullanılabilecek kaynakların, alan uzmanları ile birlikte incelenmesi sonucu belirlenmiştir (Ayvac1, 2017; Gümüş, 2017; Karaoğlu, 2013). $\mathrm{Bu}$ kavramlar; konum, yer değiştirme, ortalama hız, ortalama sürat ve ivmedir. Çalışmaya katılan öğrencilerden, bu kavramların gerçek yaşamdaki uygulamalarına örnek vermeleri istenmiştir. $\mathrm{Bu}$ kapsamda hazırlanan formda beş adet açık uçlu soru yer almakta olup formdaki sorulara bir örnek, aşağıdaki gibidir:

'Ortalama hız kavramına günlük yaşamdan bir örnek verecek olsanız hangi örneği verirdiniz?'

Hazırlanan form, iki fizik eğitimi ve bir sınıf eğitimi alan uzmanının görüşüne sunularak formun kapsam ve görünüş geçerliği sağlanmıştır. Formun pilot çalışması, Türkiye'nin batısında bulunan başka bir devlet üniversitesinde sınıf öğretmenliği programında öğrenim görmekte olan 50 öğrenci ile gerçekleştirilmiştir. Bu çalışma sonucunda, soruların öğrenciler tarafından anlaşılabilirliği teyit edilmiş ve veri analizinde karşılaşlabilecek kategoriler belirlenmiştir.

Öğrencilerin başarı motivasyonlarını belirlemek için kullanılan BOM Ölçeği, Semerci (2010) tarafından geliştirilmiştir. Bu ölçek ile eğitim fakültelerinde öğrenim gören öğrencilerin başarıları ile motivasyonları arasındaki ilişkinin belirlenmesi amaçlanmıştır. Çalışma grubu, sınıf öğretmeni adaylarından oluşmaktadır ve bu öğretmen adayları, gelecekte diğer temel dersler ile birlikte fen bilimleri dersi kapsamında bazı fizik konularının da öğretimini yapacaktır. Ayrıca, uygulanan öğretim ile araştırılan kavramların günlük yaşam ilişkilerine dikkat çekilmek istenmektedir. Bu nedenlerle, yapılan çalışmada özel olarak bir fizik motivasyon ölçeği yerine daha genel bir motivasyon ölçeği tercih edilmiştir. Böylece uygulanan öğretim yaklaşımının öğrencilere başarı açısından motivasyon sağlamada ne kadar etkili olduğu test edilmiştir. BOM Ölçeği, 5'li Likert tarzda olup 35 maddeden oluşmaktadır. Ölçekteki maddelerin 34'ü olumlu, 1'i ise olumsuz maddedir. Ölçekteki olumlu 
maddelerde; hiç katılmıyorum için ' 1'; çoğunlukla katılmıyorum için '2'; kısmen katılıyorum için '3'; çoğunlukla katılıyorum için ' 4 '; tamamen katılıyorum için '5' puan kullanılmıştır. Olumsuz maddede ise bu puanlamanın tam tersi yapılmıştır. Ölçekten alınabilecek puanların artışı, öğrencilerin başarı odaklı motivasyonlarının yükseldiğini göstermektedir. Semerci (2010) yaptığı araştırmada, BOM Ölçeği’nin Cronbach Alfa katsayısını ,896 olarak bulmuştur.

\section{Çalışma Süreci}

Çalışma süreci başlıca üç aşamadan oluşmakta olup bu süreç, veri toplama araçlarının ön-test olarak uygulanmasını; öğretim aşamasını ve aynı veri toplama araçlarının son-test olarak uygulanmasını içermektedir. Bu süreçte bazı öğrencilerin, araştırmanın ilk ve son aşamasına eksik katılım gösterdiği belirlenmiştir. Bu nedenle araştırmanın verileri, çalışmanın hem ilk hem de son aşamasına katılan öğrencilerden sağlanmıştır.

Çalışmanın öğretim aşaması, iki haftalık bir süreci kapsamıştır. Yapılan öğretim, YÖK tarafından belirlenen programa uygun olacak şekilde, haftada iki ders saati içinde gerçekleştirilmiştir. Bu süreçte mekanik kapsamında tek boyutta hareket konusu üzerinde durulmuştur.

Çalışmada gerçekleştirilen öğretimde, İki Dünya Kuramsal Çerçevesi'nden yararlanılmıştır. Öğretim sürecinde, araştırmacılar tarafindan, kavramlar ile ilişkili, öğrencilerin dikkatini çekecek ve günlük yaşamda karşılaşılabilecek örnek olaylar tasarlanmıştır. İki Dünya Kuramsal Çerçevesi’ne göre derslerde öğrencilere sunulan olaylar ve bunlara karşılık gelen kuram ve yasalara ait bazı örnekler, Tablo 1'de özetlenmektedir.

Tablo 1.

Konuların ögretiminde yararlanılan olay ve kuramlara örnekler

\begin{tabular}{|c|c|c|c|}
\hline Konu & Kavramlar & İki Dünya Kuram & Çerçevesi \\
\hline \multirow{8}{*}{$\begin{array}{l}\text { Tek Boyutta } \\
\text { Hareket }\end{array}$} & \multirow[t]{2}{*}{$\begin{array}{l}\text { Konum, } \\
\text { Yer } \\
\text { Değiştirme }\end{array}$} & $\begin{array}{l}\text { Obje-olaylar } \\
\text { dünyası }\end{array}$ & $\begin{array}{l}\text { Bir öğrenci sabah } 8.30 \text { 'da evden çıkıp okula gider. } \\
\text { Aynı öğrenci akşam okuldan çıktıktan sonra bir } \\
\text { kırtasiye ve bir markete uğrayıp saat } 17.00 \text { 'da evine } \\
\text { geri döner. Bu öğrencinin gün boyu bulunduğu } \\
\text { konumlar ve sabah } 8.30 \text { ile akşam } 17.00 \text { arasındaki yer } \\
\text { değiştirmesi kroki yardımıla incelenir. }\end{array}$ \\
\hline & & $\begin{array}{l}\text { Model-kuramlar } \\
\text { dünyası }\end{array}$ & $\Delta \vec{x}=\vec{\chi}_{\mathrm{son}}-\vec{\chi}_{\mathrm{ilk}}$ \\
\hline & \multirow[t]{2}{*}{$\begin{array}{l}\text { Ortalama } \\
\mathrm{H} 1 \mathrm{z}\end{array}$} & $\begin{array}{l}\text { Obje-olaylar } \\
\text { dünyası }\end{array}$ & $\begin{array}{l}\text { Olimpiyat oyunlarındaki koşular, } 400 \text { m'lik elips } \\
\text { şeklinde bir pistte gerçekleştirilir. } 100 \mathrm{~m} \text { koşusu ise bu } \\
\text { pistin düz olan kısmında yapılır. Her atletin koşuyu } \\
\text { tamamlama süresi kronometre ile ölçülür. Bu oyunlara } \\
\text { katılan atletlerin hareketi, ortalama hız açısından } \\
\text { aşağıda belirtilen mesafeler için incelenir: } \\
\qquad 100 \mathrm{~m} \text { koşusu } \\
\quad 400 \mathrm{~m} \text { koşusu } \\
\quad 800 \mathrm{~m} \text { koşusu }\end{array}$ \\
\hline & & $\begin{array}{l}\text { Model-kuramlar } \\
\text { dünyası }\end{array}$ & $\vec{V}$ ort $=\frac{\Delta \vec{x}}{\Delta t}$ \\
\hline & \multirow[t]{2}{*}{$\begin{array}{l}\text { Ortalama } \\
\text { Sürat }\end{array}$} & $\begin{array}{l}\text { Obje-olaylar } \\
\text { dünyası }\end{array}$ & $\begin{array}{l}\text { Bir araba yarışında kullanılan pist uzunluğu } 5,5 \\
\text { km'dir ve yarış } 50 \text { turdan oluşmaktadır. Bu yarışa } \\
\text { katılan bir yarış otomobilinin yarışı tamamlama süresi } \\
\text { ölçülür. Bu otomobilin yarış boyunca yaptığı hareket, } \\
\text { ortalama sürat açısından tartış1lır. }\end{array}$ \\
\hline & & $\begin{array}{l}\text { Model-kuramlar } \\
\text { dünyası }\end{array}$ & Ortalama sürat $=$ alınan yol $/$ toplam zaman \\
\hline & \multirow[t]{2}{*}{ İvme } & $\begin{array}{l}\text { Obje-olaylar } \\
\text { dünyası }\end{array}$ & $\begin{array}{l}\text { Durgun halde bulunan bir trafik polisi, sabit hızla ve } \\
\text { hız limitlerinin üzerinde giden bir aracı yakalamak } \\
\text { için harekete geçer. Polis aracının hareketi, sabit } \\
\text { ivmeli hareket olarak kabul edilir. Bu hareket, } \\
\text { zamanla alınan yol bakımından incelenir. }\end{array}$ \\
\hline & & $\begin{array}{l}\text { Model-kuramlar } \\
\text { dünyası }\end{array}$ & $\Delta x=v_{i} t+1 / 2 a t^{2}$ \\
\hline
\end{tabular}


Öğretim sürecinde dersler üç aşama halinde planlanmıştır. Dersin başlangıcında öğrencilere, obje-olaylar dünyasından sunulan örnekler ile öğrencilerin dikkati derse çekilmeye çalışılmış ve öğrencilere sunulan olgu-olaylar sınıf içinde tartışılmıştır. Bu kapsamda, sınıf içinde yapılabilecek bazı demonstrasyonlar ile günlük yaşam örneklerinden yararlanılmıştır. Örneğin, sınıf içerisinde bir öğrencinin bir referans noktasına göre konumu metre yardımıyla ölçülerek belirlenmiştir. Daha sonra öğrencinin yer değiştirmesi sağlanarak son konumu belirlenmiştir. Son konum ve ilk konum arasındaki fark gözlenerek öğrencilere yer değiştirme kavramı gösterilmiştir. Ardından, öğrencilere modelkuramlar dünyasından kavramsal bilgiler sunulmuş ve öğrencilerden bu bilgileri, onlara başlangıçta sunulan olgu ve olaylarla ilişkilendirmeleri istenmiştir. Bu aşamada, sınıf içinde yapılan tartışmalar ile öğrencilerin öğretmen rehberliğinde bilgilerini yapılandırması sağlanmıştır. Son aşamada ise konuyla ilgili problem çözümleri yapılarak dersin değerlendirmesi yapılmıştır.

\section{Verilerin Analizi}

Çalışmanın verileri; ön-test, son-test şeklinde toplandığı için veri analizine öncelikle aynı öğrencilerden elde edilen veri toplama araçlarının aynı sayı ile kodlanmasıyla başlanmıştır. Böylece uygulanan ön-test ve son-testlerin karşılaştırılması amaçlanmıştır.

MKGYIF'den elde edilen verilerin analizinde, hem nitel hem de nicel yöntemlerden yararlanılmıştır. İlk olarak öğrencilerin verdiği örnekler, nitel yöntemlerden içerik analizine tabi tutulmuştur (Büyüköztürk ve diğerleri, 2010). Bu işlemde, her bir kavram için öne sürülen örnekler, iki araştırmacı tarafından tek tek incelenmiştir. Bu inceleme sonucunda öğrenciler tarafından verilen örnekler, günlük yaşam ile ilişkili örnekler (GYiÖ) ve günlük yaşam ile ilişkili olmayan örnekler (GYİÖ) olmak üzere iki tema altında toplanmıştır. Bu temalara dahil edilen kodlar, Tablo 2'de özetlenmektedir.

Tablo 2.

MKGYIF'den elde edilen verilerin analizinde kullanılan temalar ve kodlar

\begin{tabular}{ll}
\hline Temalar & \multicolumn{2}{c}{ Kodlar ve Açıklamaları } \\
\hline $\begin{array}{l}\text { Günlük yaşam ile ilişkili } \\
\text { örnekler (GYİÖ) }\end{array}$ & $\bullet \begin{array}{l}\text { Verilen kavramların günlük yaşamdaki uygulama alanlarıyla ilgili doğru } \\
\text { Örnekler }\end{array}$ \\
\hline $\begin{array}{l}\text { Günlük yaşam ile ilişkili } \\
\text { olmayan örnekler }\end{array}$ & $\bullet$ Verilen kavramın doğru kabul edilebilecek tanımı \\
(GYİOÖ) & $\bullet$ İlişkisiz/belirsiz yanıtlar \\
& $\bullet$ Yanlış yanıtlar \\
\hline
\end{tabular}

Daha önce belirtildiği gibi bu çalışmanın amaçlarından birisi, öğrencilerin verdikleri günlük yaşam ile ilişkili kabul edilebilir örneklerin belirlenmesidir. Bu nedenle, Tablo 2'den anlaşılacağ üzere araştırmada ele alınan kavramların günlük yaşam ile ilişkili ve doğru örnekleri, GYİÖ kategorisi altında toplanmıştır. Buna karşılık doğru günlük yaşam uygulaması sunmayan bütün yanıtlar, GYÏÖ kategorisi dışında bırakılmıştır. GYIOÖ kategorisine; ilişkisiz/belirsiz yanıtlar, yanlış yanıtlar, yanıtsız bırakılan kavramlar ile öğrencilerin araştırma sorusu için verilen kavramlar ile ilgili yaptıkları doğru kabul edilebilecek tanımları da dahildir. Başka bir ifade ile çalışmada, doğru günlük yaşam uygulamaları araştırıldığından öğrenciler tarafından yapılan doğru kabul edilebilecek tanımlar, GYİOÖ kategorisine dahil edilmiştir. Kavramların bilimsel açıdan doğru kabul edilebilir tanımları, öğrencilerin bu kavramlarla ilgili bilgi düzeyinde bulunduklarını gösterirken kavramlarla ilgili doğru örnekler verebilmeleri ise uygulama düzeyinde olduklarını göstermektedir. Bu nedenlerle çalışmanın amacı doğrultusunda doğru kabul edilebilir tanımlar, GYİOÖ kategorisinde değerlendirilmiştir.

Analiz sürecinde, veri analizinin güvenirliğini belirlemede, araştırmacılar arası tutarlık katsayısı hesaplanmıştır. Veri analizinde araştırmacılar arası tutarlık katsayısı, p; görüş ayrılıkları ve görüş birliklerinden yararlanılarak hesaplanmıştır (Miles \& Huberman, 1994). Bu katsayı, \%90,9 olarak bulunmuştur. Elde edilen değer \% 70'in üzerinde olduğundan yapılan veri analizinin güvenilir olduğu söylenebilir (Yıldırım \& Şimşek, 2008). Araştırmacılar arasında görüş ayrılığı yaratan örneklerin kodlarının belirlenmesinde ise üçüncü araştırmacının görüşüne başvurularak bu kodlar belirlenmiştir.

Nitel analiz sonucunda MKGYİ'den elde edilen veriler, GYIÖ ve GYİÖ temaları altında toplanarak frekans ve yüzde dağılımları ile nicelleştirilmiştir. Ayrıca, öğrencilerin kavramları günlük 
yaşam uygulamalarıyla ilişkilendirmelerinde ön-test ve son-test arasında istatistiksel açıdan anlamlı bir farklılık olup olmadığını belirlemek için parametrik olmayan testlerden Wilcoxon işaretli sıralar testinden yararlanılmıştır. Parametrik testlerden bağımlı örneklemler için t-testinin alternatifi sayılabilecek Wilcoxon işaretli sıralar testi, veri setinde normallik koşulunun sağlanmadığı durumlarda kullanılır. Ayrıca, bağımlı değişkenin en az sıralama ölçeğinde ve gözlem çiftlerinin birbiri ile ilişkili olmasını da gerektirir (Büyüköztürk, 2010). Bu analizde, ilk olarak her bir öğrenciden, araştırılan her bir kavram için ön-test ve son-testte elde edilen GYIOÖ'ler, '1'; GYİOÖ’ler ise '0' ile puanlanmıştır. Bu puanlama sonuçları, bilgisayar ortamına aktarılarak her bir kavramın ön-test ve son-test uygulamasına ait veri setleri, tek örneklem Kolmogorov Smirnov testi (K-S testi) ile normallik açısından incelenmiştir. Yapılan analiz sonucunda bütün kavramlara ait veri seti dağılımların $p$ istatistik değeri ,0001 bulunarak ,05 anlamlılık düzeyinin altında kaldığ (Büyüköztürk, 2010). Bu nedenle, öğrencilerin verilen kavramları günlük yaşam ile ilişkilendirebilme durumları, kavram bazında yapılan karşılaştırmalar ile ,05 anlamlılık düzeyinde IBM SPSS 20 kullanılarak Wilcoxon işaretli sıralar testi yardımıyla incelenmiştir.

BOM Ölçeği'nden elde edilen verilerin analizinde ise nicel yöntemler izlenmiş olup ilk olarak her bir öğrenciden elde edilen ölçek için puanlama yapılmıştır. Ardından, yapılan puanlamalar bilgisayar ortamına aktarılarak IBM SPSS 20 ile analiz edilmiştir. BOM Ölçeği'nden elde edilen verilerin analizinde kullanılacak testin türüne karar vermeden önce ön-test ve son-testten elde edilen veriler, betimsel istatistik yöntemleriyle incelenmiş ve her bir veri seti için histogramlar çizilmiştir. Ayrıca, her bir veri seti için puanların normal dağılım gösterip göstermediğini belirlemek amacıyla tek örneklem K-S testi yapılmıştır. K-S testi sonucunda, ön-testten elde edilen BOM puanları için $p$ istatistik değeri ,562; son-testten elde edilen $\mathrm{p}$ istatistik değeri ise ,073 bulunmuştur. Bu değerler, her

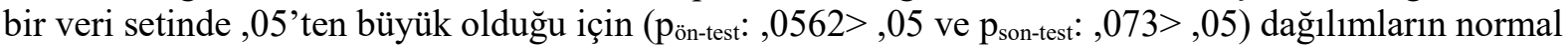
dağglımdan sapma göstermediğine karar verilmiştir (Büyüköztürk, 2010). Bu nedenle, öğrencilerin BOM Ölçeği puanlarının ön-test ve son-test arasında karşılaştırılmasında parametrik testlerden, ilişkili örneklemler için t-testi kullanılmıştır.

Yapılan çalışmada, BOM Ölçeği'nin 53 katılımcıya ön-test uygulaması sonucunda elde edilen verilerin Cronbach Alfa katsayısı ,896; son-test uygulaması sonucunda ise ,940 olarak belirlenmiştir. $\mathrm{Bu}$ değerler, her iki uygulama için de ,70'in üzerinde olduğundan verilerin güvenilir olduğunu göstermektedir (Büyüköztürk, 2010).

\section{BULGULAR}

Öğrencilerin, ön-test ve son-test uygulamaları sonucunda, beş mekanik kavramı için ileri sürdüğü örneklerin betimsel analizinden ve Wilcoxon işaretli sıralar testi ile karşılaştırılmasından elde edilen bulgular, aşağıda sunulmaktadır.

Tablo 3.

Konum kavramı ile ilgili verilen örneklerin betimsel analizi

\begin{tabular}{|c|c|c|c|}
\hline \multirow{2}{*}{ Temalar } & \multicolumn{2}{|c|}{$\mathrm{f}(\%)$} & \multirow{2}{*}{ Örnek Cevaplar } \\
\hline & Ön-Test & Son-Test & \\
\hline GYİÖ & $10(\% 18,9)$ & $29(\% 54,7)$ & - $\quad$ Bir koşucunun başlangıç noktasına göre yeri \\
\hline GYİOÖ & $43(\% 81,1)$ & $24(\% 45,3)$ & $\begin{array}{ll}\text { - } & \text { Tanım } \\
\text { - } & \text { Bulunulan nokta veya erişmemiz gereken yer } \\
\text { - } & \text { Belirsiz/İlişkisiz Yanıtlar } \\
\text { - } & \text { Okulda bekliyorum. } \\
\text { - } & \text { Evimin bulunduğu yer, mahalle } \\
\text { - } & \text { Arkadaşımızla buluşurken onun olduğu yere onu } \\
& \text { bekletmeyecek hızla gitmek } \\
\text { - } & \text { Yanlış Yanıtlar } \\
\text { - } & \text { Bir şeyin hareketsiz bulunduğu yer }\end{array}$ \\
\hline
\end{tabular}

Konum kavramıla ile ilgili Tablo 3'te yer alan bulgular incelendiğinde, ön-test sonucunda öğrencilerin çoğundan $(\% 81,1)$ GYİOÖ elde edilirken son-test sonucunda ise öğrencilerin yarısından fazlasının (\%54,7) GYİÖ ileri sürdüğü tespit edilmiştir. 
Tablo 4.

Konum kavramı ile ilgili örneklerin son-test - ön-test arasındaki değişimi

\begin{tabular}{lccccc}
\hline Son-Test - Ön-Test & $\mathrm{n}$ & Sira Ortalamas1 & Sira Toplami & $\mathrm{z}$ & $\mathrm{p}$ \\
\hline Negatif sıra & $1^{\mathrm{a}}$ & 11,00 & 11,00 & $4,146^{*}$ &, 0001 \\
Pozitif sıra & $20^{\mathrm{b}}$ & 11,00 & 220,00 & & \\
Eşit & $32^{\mathrm{c}}$ & & & & \\
Toplam & 53 & & & & \\
\hline
\end{tabular}

*Negatif sıralar temeline dayalıdır. Not: a. son-test $<$ ön-test; b. son-test $>$ ön-test; c. son-test=ön-test

Tablo 4'e göre ön-test ve son-test uygulamalarında konum kavramı ile ilgili verilen örnekler, Wilcoxon işaretli sıralar testi yardımıyla karşılaştırıldığında, her iki uygulama arasında istatistiksel açıdan anlamlı bir farklılık olduğu tespit edilmiştir $(\mathrm{z}=4,146, \mathrm{p}<, 05)$. Son-test sonucunda GYİOÖ'deki azalma ve GYİÖ'deki artış göz önünde bulundurulduğunda, yapılan uygulamanın öğrencilerin konum kavramını günlük yaşam ile bağdaştırmalarına katkılarda bulunduğu söylenebilir.

Tablo 5 .

Yer değiştirme kavramı ile ilgili verilen örneklerin betimsel analizi

\begin{tabular}{|c|c|c|c|}
\hline \multirow{2}{*}{ Temalar } & \multicolumn{2}{|c|}{$\mathrm{f}(\%)$} & \multirow{2}{*}{ Örnek Cevaplar } \\
\hline & Ön-Test & Son-Test & \\
\hline GYİÖ & $27(\% 50,9)$ & $51(\% 96,2)$ & $\begin{array}{ll}\text { - } & \text { Sinıftan çıkıp eve gitmek } \\
\text { - } & \text { Masanın sağ köşesinde olan suyu sol köşesine } \\
\text { taşımak }\end{array}$ \\
\hline GYİOÖ & $26(\% 49,1)$ & $2(\% 3,8)$ & $\begin{array}{ll}\text { - } & \text { Tanım } \\
\text { - } & \text { Bir konumdan başka konuma geçilmesi } \\
\text { - } & \text { Belirsiz/İlişkisiz Yanitlar } \\
\text { - } & \text { Otobüs } \\
\text { - } & \text { Futbol topu } \\
\text { - } & \text { Günlük hareketler } \\
\text { - } & \text { Yanlış Yanıtlar } \\
\text { - } & \text { Bir cismin hareket etmesi } \\
\end{array}$ \\
\hline
\end{tabular}

Tablo 5'e göre yer değiștirme kavramı incelendiğinde, ön-test sonucunda öğrencilerin yaklașık olarak yarısından (\%49,1) GYİOÖ, diğer yarısından (\%50,9) ise GYIÖ elde edildiği belirlenmiştir. Sontest sonucunda ise öğrencilerin büyük çoğunluğundan $(\% 96,2)$ GYİÖ elde edilmiştir.

Tablo 6.

Yer değiştirme kavramı ile ilgili örneklerin son-test-ön-test arasındaki değişimi

\begin{tabular}{lccccc}
\hline Son-Test - Ön-Test & $\mathrm{n}$ & Sira Ortalamas1 & Sira Toplam1 & $\mathrm{z}$ & $\mathrm{p}$ \\
\hline Negatif sira & $0^{\mathrm{a}}$ &, 00 &, 00 & $4,899^{*}$ &, 0001 \\
Pozitif sıra & $24^{\mathrm{b}}$ & 12,50 & 300,00 & & \\
Eşit & $29^{\mathrm{c}}$ & & & & \\
Toplam & 53 & & & & \\
\hline
\end{tabular}

*Negatif siralar temeline dayalıdır. Not: a. son-test<ön-test; b. son-test>ön-test; c. son-test=ön-test

Tablo 6'dan anlaşılacağı üzere, yer değiştirme kavramı ile ilgili verilen örnekler, ön-test ve sontest arasında Wilcoxon işaretli sıralar testi ile karşılaştırıldığında, iki uygulama arasında son-test lehine istatistiksel açıdan anlamlı bir farklılık belirlenmiştir $(z=4,899, p<, 05)$. Daha önce bahsedilen konum kavramına benzer bir şekilde, yapılan uygulamanın öğrencilerin yer değiştirme kavramını günlük yaşam ile bağdaştırmalarına olumlu etkilerde bulunduğu söylenebilir. 
Tablo 7.

Ortalama hız kavramı ile ilgili verilen örneklerin betimsel analizi

\begin{tabular}{|c|c|c|c|}
\hline \multirow{2}{*}{ Temalar } & \multicolumn{2}{|c|}{$\mathrm{f}(\%)$} & \multirow{2}{*}{ Örnek Cevaplar } \\
\hline & Ön-Test & Son-Test & \\
\hline GYİÖ & $8(\% 15,1)$ & $15(\% 28,3)$ & $\begin{array}{ll}\text { - } & \text { Araç, } 100 \mathrm{~km} / \mathrm{h} \text { hızla batıya doğru ilerliyor. } \\
\text { - } & \text { Rüzgârın esiş yönü ve büyüklüğ̈u }\end{array}$ \\
\hline GYİOÖ & $45(\% 84,9)$ & $38(\% 71,7)$ & $\begin{array}{ll}\text { - } & \text { Belirsiz/İlişkisiz Yanıtlar } \\
\text { - } & \text { Formula } 1 \text { yarışlarındaki arabalar } \\
\text { - } & \text { Uçağın uçuşu } \\
\text { - } & \text { Ortalamanın üstündeki gidiş } \\
\text { - } & \text { Yanlıs Yanıtlar } \\
\text { - } & \text { Yürürken adımlarımızı sıklaştırma } \\
\text { - } & \text { Bir cismin hareket ederken kullandığı kuvvet } \\
\text { - } & \text { Bir aracın gittiği yolun, ne kadar zamanda } \\
& \text { gittiğine oranı }\end{array}$ \\
\hline
\end{tabular}

Tablo 7 dikkate alındığında, ön-test sonucunda ortalama hız kavramı ile ilgili belirlenen GYİÖ oranının $(\% 15,1)$, konum ve yer değiştirme kavramlarının ön test bulgularına göre düşük kaldığı görülmektedir. Son-test sonucunda ortalama hız kavramı ile ilgili GYİÖ oranının $(\% 28,3)$ ön-teste göre artış gösterdiği; ancak son-test sonucunda ortaya çıkan GYIOÖ oranının $(\% 71,7)$, GYİÖ $(\% 28,3)$ oranından daha yüksek olduğu belirlenmiştir.

Tablo 8.

Ortalama hız kavramı ile ilgili örneklerin son-test-ön-test arasındaki değişimi

\begin{tabular}{lccccc}
\hline Son-Test - Ön-Test & $\mathrm{n}$ & Sira Ortalamas1 & Sira Toplam1 & $\mathrm{z}$ & $\mathrm{p}$ \\
\hline Negatif sıra & $6^{\mathrm{a}}$ & 10,00 & 60,00 & $1,606^{*}$ &, 108 \\
Pozitif sıra & $13^{\mathrm{b}}$ & 10,00 & 130,00 & & \\
Eşit & $34^{\mathrm{c}}$ & & & & \\
Toplam & 53 & & & & \\
\hline
\end{tabular}

*Negatif sıralar temeline dayalıdır. Not: a. son-test< $<$ ön-test; b. son-test $>$ ön-test; c. son-test=ön-test

Tablo 8'den anlaşılacağı üzere, ortalama hız kavramı ile ilgili verilen iki kategorideki örnekler, ön-test ve son-test açısından Wilcoxon işaretli sıralar testi ile karşılaştırıldığında her iki uygulama arasında istatistiksel açıdan anlamlı bir farklılık olmadığı belirlenmiştir $(\mathrm{z}=1,606, \mathrm{p}>, 05)$. Yapılan uygulama sonucunda öğrencilerin verdikleri GYİOÖ’lerde azalma, GYİÖ'lerde ise artış tespit edilmiş fakat bu değişimin istatistiksel olarak anlamlı olmadığı bulunmuştur.

Tablo 9.

Ortalama sürat kavramı ile ilgili verilen örneklerin betimsel analizi

\begin{tabular}{|c|c|c|c|}
\hline \multirow{2}{*}{ Temalar } & \multicolumn{2}{|c|}{$\mathrm{f}(\%)$} & \multirow{2}{*}{ Örnek Cevaplar } \\
\hline & Ön-Test & Son-Test & \\
\hline GYİÖ & $1(\% 1,9)$ & $33(\% 62,3)$ & $\begin{array}{l}\text { - Okuldan eve geldiğimizde aldığımız toplam } \\
\text { yolu toplam zamana oranladığımızda ortalama } \\
\text { süratimizi buluruz. } \\
100 \text { metreyi } 10 \text { saniyede koşmamız } 10 \mathrm{~m} / \mathrm{s} \\
\text { ortalama sürat yaptığımızı gösterir. }\end{array}$ \\
\hline GYİOÖ & $52(\% 98,1)$ & $20(\% 37,7)$ & $\begin{array}{ll}\text { - } & \text { Tanım } \\
\text { - } & \text { Toplam yol/geçen zaman=skaler büyüklüktür. } \\
\text { - } & \text { Belirsiz/İlişkisiz Yanitlar } \\
\text { - } & \text { Bir sporcunun bir pistte koşarak } 2 \text { tur atması } \\
\text { - } & \text { Yarış arabaları } \\
\text { - } & \text { Yanlış Yanıtlar } \\
\text { - } & \text { Sürat = çok hız } \\
\text { - } & \text { Hızlı bir bisikletin yol alması }\end{array}$ \\
\hline
\end{tabular}


- $\quad$ Belirli bir hızla hareket eden at arabasının $\mathrm{m} / \mathrm{s}$ cinsinden hizı

- Toplam yoldur. 3 adım ileri 1 adım geri giden toplam 4 adım yol almış olur.

Tablo 9'a göre ortalama sürat kavramı ile ilgili örnekler incelendiğinde, ön-test sonucunda GYİÖ veren bir katılımcı $(\% 1,9)$ hariç bütün katılımcılardan $(\% 98,1)$ GYİOÖ elde edildiği; son-test sonucunda ise GYİÖ oranının $(\% 62,3)$ artış gösterdiği görülmektedir.

Tablo 10.

Ortalama sürat kavramı ile ilgili örneklerin son-test-ön-test arasındaki değiş̧imi

\begin{tabular}{lccccc}
\hline Son-Test - Ön-Test & $\mathrm{n}$ & Sira Ortalamas1 & Sira Toplami & $\mathrm{z}$ & $\mathrm{p}$ \\
\hline Negatif sıra & $0^{\mathrm{a}}$ &, 00 &, 00 & $5,657^{*}$ &, 0001 \\
Pozitif sıra & $32^{\mathrm{b}}$ & 16,50 & 528,00 & & \\
Eşit & $21^{\mathrm{c}}$ & & & & \\
Toplam & 53 & & & & \\
\hline
\end{tabular}

*Negatif sıralar temeline dayalıdır. Not: a. son-test<ön-test; b. son-test>ön-test; c. son-test=ön-test

Tablo 10'da ortalama sürat kavramı ile ilgili verilen örneklerin, Wilcoxon işaretli sıralar testi ile ön-test ve son-test açısından karşılaştırıldığı ve bu iki uygulama arasında istatistiksel açıdan anlamlı bir farklılık ortaya çıktığı görülmektedir $(z=5,657, p<, 05)$. Son-test sonucunda GYİÖ’lerdeki artış ve GYİOÖ’lerdeki azalmanın, gerçekleştirilen uygulamanın olumlu sonuçlarına dayandığı söylenebilir.

Tablo 11.

Íme kavramı ile ilgili verilen örneklerin betimsel analizi

\begin{tabular}{|c|c|c|c|}
\hline \multirow{2}{*}{ Temalar } & \multicolumn{2}{|c|}{$f(\%)$} & \multirow{2}{*}{ Örnek Cevaplar } \\
\hline & Ön-Test & Son-Test & \\
\hline GYİÖ & $13(\% 24,5)$ & $35(\% 66,0)$ & $\begin{array}{l}\text { - } 10 \mathrm{~m} / \mathrm{s} \text { hızla giden bir aracın hızını } 16 \mathrm{~m} / \mathrm{s}^{\prime} y e \\
\text { çıarması } \\
\text { - Kullandığımız aracın giderek hızlanması } \\
\text { - } \quad \text { Yolda giden bir arabanın aniden yön } \\
\text { değiştirmesi }\end{array}$ \\
\hline GYİOÖ & $40(\% 75,5)$ & $18(\% 34,0)$ & $\begin{array}{ll}\text { - } & \text { Tanım } \\
\text { - } & \text { Hızın zamana göre değişimi } \\
\text { - } & \text { Belirsiz/İlişkisiz Yanıtlar } \\
\text { - } & \text { Ipp atlıyorum. } \\
\text { - } & \text { Hızlar farkının geçen zaman farkına oranı } \\
\text { - } & \text { Yanlış Yanıtlar } \\
\text { - } & \text { Arabanın hızlanırken saniyede aldığı yol } \\
\text { - } & \text { Arabanın geri gitme hareketi }\end{array}$ \\
\hline
\end{tabular}

Tablo 11 'de yer alan ivme kavramı ile ilgili verilen örneklerin dağılımı incelendiğinde, son-test sonucunda öğrencilerin ileri sürdüğü GYİÖ oranının $(\% 66,0)$, diğer kavramlara benzer bir şekilde, önteste göre $(\% 24,5)$ artış gösterdiği belirlenmiştir.

Tablo 12.

Ívme kavramı ile ilgili örneklerin son-test - ön-test arasındaki değişimi

\begin{tabular}{lccccc}
\hline Son-Test - Ön-Test & $\mathrm{n}$ & Sira Ortalamas1 & Sira Toplam1 & $\mathrm{z}$ & $\mathrm{p}$ \\
\hline Negatif sira & $3^{\mathrm{a}}$ & 14,00 & 42,00 & $4,041^{*}$ &, 0001 \\
Pozitif sira & $24^{\mathrm{b}}$ & 14,00 & 336,00 & & \\
Eşit & $26^{\mathrm{c}}$ & & & & \\
Toplam & 53 & & & & \\
\hline
\end{tabular}

*Negatif sıralar temeline dayalıdır. Not: a. son-test<ön-test; b. son-test>ön-test; c. son-test=ön-test 
Tablo 12'ye göre, ivme kavramı ile ilgili verilen iki kategorideki örnekler, ön-test ve son-test açısından Wilcoxon işaretli sıralar testi ile karşılaştırıldığında her iki uygulama arasında istatistiksel açıdan anlamlı bir farklılık olduğu tespit edilmiştir $(\mathrm{z}=4,041, \mathrm{p}<, 05)$. Bu durum, ortalama hız kavramı hariç diğer kavramlara benzer bir şekilde, yapılan uygulamanın olumlu bir etkisi şeklinde yorumlanabilir.

Yukarıda bahsedilen bulgular genel olarak değerlendirildiğinde; araştırmaya konu edilen bütün mekanik kavramları için son-test sonucunda elde edilen GYIÖ oranının, ön-teste göre artış gösterdiği; GYİOÖ oranının ise azaldığı tespit edilmiştir. Ayrıca, ön-test ve son-testten elde edilen örnekler, istatistiksel olarak karşılaştırıldığında; ortalama hız kavramı hariç diğer bütün kavramlar için belirlenen artış ve azalmaların, istatistiksel açıdan anlamlı olduğu görülmektedir. Elde edilen bulgulara göre İki Dünya Kuramsal Çerçevesi'nin öğrencilerin ortalama hız kavramı hariç ele alınan diğer bütün mekanik kavramları için günlük yaşam bağlantıları kurmalarında anlamlı etkiler yarattığı söylenebilir.

Öğrencilerin, BOM Ölçeği'nden aldıkları puanların ön-test ve son-test uygulamaları için karşılaştırılmasından elde edilen bulgular, Tablo 13'te yer almaktadır.

Tablo 13.

Öğrencilerin bom ölçeği puanlarının karşılaştırması

\begin{tabular}{lcccccc}
\hline Uygulama & $\mathrm{N}$ & $\bar{X}$ & $\mathrm{~S}$ & $\mathrm{sd}$ & $\mathrm{t}$ & $\mathrm{p}$ \\
\hline Ön-Test & 53 & 133,91 & 15,22 & 52 & 4,504 &, 0001 \\
Son-Test & 53 & 142,09 & 18,21 & & & \\
\hline
\end{tabular}

Tablo 13'ten anlaşılacağı üzere, öğrencilerin BOM Ölçeği'nden son-testte elde ettikleri puan ortalaması, ön-teste göre artmış olup bu artış istatistiksel açıdan anlamlı bir farklılık ifade etmektedir $(\mathrm{t}(52)=4,504, \mathrm{p}<, 05)$. Yapılan uygulama sonucunda, öğrencilerin başarı odaklı motivasyonlarının anlamlı derecede yükseldiği görülmektedir. Bu durumun da öğrencilerin günlük yaşam bağlantıları kurmalarında olduğu gibi İki Dünya Kuramsal Çerçevesi'nin öğrencilerin öğrenmeleri üzerinde yarattığı motivasyon artışından kaynaklandığı ileri sürülebilir.

\section{TARTIŞMA, SONUÇ ve ÖNERILER}

Çalışmadan elde edilen bulgular ışığında, İki Dünya Kuramsal Çerçevesi’nin sınıf öğretmenliği öğrencilerinin konum, yer değiştirme, ortalama hız, ortalama sürat ve ivme kavramlarını günlük yaşam ile ilişkilendirebilmelerinde olumlu etkiler gösterdiği belirtilebilir. Ayrıca, öğrencilerin başarı motivasyonlarının da bu yaklaşımdan olumlu etkilendiği ve yükseldiği görülmektedir. Bu sonuçlar, Yavuz ve Fide'nin (2010) çalışmalarında yaptıkları öneriyi destekler niteliktedir.

Çalışmanın başlangıcında yapılan ön-test sonucunda, ele alınan beş kavramın birisi hariç (yer değiştirme) dördü için öğrencilerin ileri sürdüğü GYIOÖ oranının daha yüksek olduğu görülmüştür ('konum' için \%81,1; 'ortalama hız' için \%84,9; 'ortalama sürat' için \%98,1; 'ivme' için \%75,5). Bu sonuç, çalışmanın başlangıcında, öğrencilerin kendilerine verilen kavramlar ile günlük yaşam arasında yeterince doğru bağlantılar kuramadığını göstermektedir. Ayrıca, öğrencilerin teorik bilgilerini yeterince anlamlandıramadıkları da anlaşılmaktadır. Bu durum daha önce yapılan araştırmalarda elde edilen, kimya öğretmen adaylarının kimya ile ilgili bilgilerini günlük yaşam ile ilişkilendirememeleri (Özmen, 2003; Yadigaroğlu \& Demircioğlu, 2012) ve fen bilgisi öğretmen adaylarının kimya ile ilgili bilgilerini yeni karşılaştıkları durumlar ile ilişkilendirememeleri (Yıldırım \& Birinci Konur, 2014) sonuçları ile benzerlik göstermektedir. Buna karşılık, Balkan Kıyıcı ve Aydoğdu (2011) fen bilgisi öğretmen adaylarının fizik ile ilgili teorik bilgilerini günlük yaşam ile büyük ölçüde ilişkilendirebildiklerini belirlemiştir.

Çalışmadan elde edilen bir diğer sonuç, GYİOÖ kategorisi altında elde edilen yanlış yanıtlardır. Öğrencilerin bütün kavramlar için bu tür düşünceler taşıdıkları görülmektedir. Bu yanıtların oranı, çalışma başlangıcında daha yüksektir. Bu yanıtların bazılarının literatürde belirtilen kavram yanılgıları ile benzerlik gösterdiği görülmektedir. Öğrenciler fizik derslerine, kavram yanılgısı ya da alternatif yapılar diye isimlendirilen, günlük yaşamda zihinlerinde oluşturdukları birtakım ön bilgiler ile gelebilmektedirler (Chang ve diğerleri, 2007). Çalışma sonucunda, GYİÖ oranının azalmasından anlaşılacağı üzere, öğrencilerin yanlış yanıtlarının oranının da düşüş gösterdiği söylenebilir. 
Yanlış yanıtların bulunduğu kavramlar incelendiğinde; ortalama hız kavramı için elde edilen GYİÖ’lerde, bu kavramın vektör kavramı ile ilişkilendirilememesinin etkili olduğu dikkat çekmektedir. Üniversite öğrencileri ile gerçekleştirilen başka bir çalışmada da hızın sadece bir sayı olarak algılandığı; vektör olarak algılanmadığı belirtilmektedir (Poutot \& Blandin, 2015). Bu araştırmacılar, hızın vektör ifadesi olmadan sadece sayısal bir değer olarak algılanmasını, kavram yanılgısı olarak aktarmıştırlar. Dolayısıyla yapılan çalışmada öğrencilerin ortalama hız kavramını vektör kavramı ile ilişkilendirememeleri, bu kavram yanılgısı ile paralellik göstermektedir. Bunun yanında öğrenciler, yer değiştirme kavramını hareket etmek ile açıklamaktadırlar. Nitekim literatür, öğrenciler tarafından sıfır metre yer değiştirmenin hiç uzaklık kat edilmemesi şeklinde algılandığını, öğrencilerin bu kapsamda kavram yanılgısı taşıdığını göstermektedir (Motlhabane, 2016). Yapılan çalışmada, yer değiştirme kavramı ile ilgili tespit edilen bazı yanlış yanıtlar, literatür ile benzerlik göstermektedir. Ancak, her hareket, fiziksel anlamda yer değiştirme ile sonuçlanmayabilir. Bu sonuç da vektör kavramının öğrenciler tarafından yeterince anlaşılmamasından kaynaklanabilir.

Ortalama sürat kavramıyla ilgili yanlış yanıtlar incelendiğinde; bu kavramın çok hızlı olan cisimlerin sahip olabileceği bir özellik olarak algılandığ belirlenmiştir. Bir cismin süratinin, yüksek değerler alabileceği gibi düşük değerlerde de olabileceğinin göz ardı edildiği görülmektedir. $\mathrm{Bu}$ sonucun öğrencilerin günlük yaşam deneyimlerine dayalı olarak gelişen inançlarından kaynaklandığı düşünülmektedir (Nik Daud, Abd Karim, Wan Hassan \& Abdul Rahman, 2015). Ortalama sürat kavramı, günlük yaşamda genellikle yüksek değerler ile ilişkilendirilmektedir. Literatür, üniversite öğrencilerinin hız ve sürat kavramlarını karıştırarak kavram yanılgılarına sahip olduklarına işaret etmektedir (Jones, 1983). Bunun yanında, Zengin (2018) fizik öğretmenleri ile gerçekleştirdiği bir araştırma sonucunda, ortalama süratin, hız büyüklüğü şeklinde algılandığını fakat bu düşüncenin bir kavram yanılgısından öte bilgi eksikliği olduğunu belirtmektedir.

İvme kavramı için belirlenen yanlış yanıtlar dikkate alındığında, öğrencilerin arabanın hızlanırken saniyede aldığı yol şeklindeki düşünceleri, ortalama hız ve ivme kavramlarını ayırt edemediklerini yani öğrencilerin hı ve ivme kavramlanı hakkında karmaşa yaşadıklarını göstermektedir. $\mathrm{Bu}$ sonuç da üniversite öğrencilerinin bu kavramları ayırt edemeyerek kavram yanılgıları taşıdığını belirten literatür ile benzerlik göstermektedir (Bayraktar, 2009; Fadaei \& Mora, 2015; Jones, 1983; Martín-Blas, Seidel \& Serrano-Fernández, 2010; Poutot \& Blandin, 2015).

Yanlış yanıtların yanında, öğrencilerin bazı kavramları tam olarak ifade etmek yerine zihinlerindeki olguları örnek olarak sunarak belirsiz ya da ilişkisiz cevaplar verdikleri bulunmuştur. $\mathrm{Bu}$ duruma örnek olarak, ortalama hız denilince Formula 1 yarış arabası; konum denilince evin bulunduğu mahalle; yer değiştirme denilince otobüs; ortalama sürat denilince pistte iki tur atmak; ivme denilince ip atlamak şeklinde yanıtların verilmesi gösterilebilir.

$\mathrm{Bu}$ araştırmada İki Dünya Kuramsal Çerçevesi'nden yararlanılarak gerçekleştirilen öğretim sonucunda, araştırmaya konu edilen bütün mekanik kavramları için ileri sürülen GYİÖ oranının çalışmanın başlangıcına göre artış gösterdiği belirlenmiştir ('konum' için \%18,9'dan \%54,7'ye; 'yer değiştirme' için \%50,9'dan \%96,2'ye; 'ortalama hız' için \%15,1'den \%28,3'e; 'ortalama sürat' için $\% 1,9$ 'dan \%62,3'e; 'ivme' için \%24,5'ten \%66,0'a ulaşılmıştır.). Öğrencilerin kendilerine verilen kavramları günlük yaşam ile ilişkilendirebilme durumları istatistiksel açıdan incelendiğinde ise, elde edilen farkın, ortalama hız kavramı hariç diğer bütün kavramlarda anlamlı olduğu görülmektedir. Dolayısıyla, İki Dünya Kuramsal Çerçevesi’nin, öğrencilerin ortalama hız kavramı hariç diğer bütün mekanik kavramlarını günlük yaşam ile ilişkilendirmelerinde olumlu yönde, anlamlı bir etki yarattığı söylenebilir. Böylece, katılımcıların kendilerine verilen mekanik kavramlarının günlük yaşam uygulamalarını doğru örnekler ile ilişkilendirerek açıklayabildikleri görülmüş̧ür.

Yukarıda bahsedildiği üzere ortalama hız kavramı için benzer bir sonuç elde edilememesinin sebebi, literatürde de belirtildiği gibi bu kavramın öğrenciler tarafindan hem ivme (Bayraktar, 2009; Fadaei \& Mora, 2015; Jones, 1983; Martín-Blas, Seidel \& Serrano-Fernández, 2010; Poutot \& Blandin, 2015) hem de konum kavramları ile karıştırılması (Fadaei \& Mora, 2015; Poutot \& Blandin, 2015; Trowbridge \& McDermott, 1980); vektör kavramı ile ilişkilendirilememesi (Poutot \& Blandin, 2015); dolayısıyla bu kavramın öğrenciler açısından anlaşılması zor bir kavram olması şeklinde açıklanabilir. Nitekim fizik öğretmenlerinin de farklı yönlerde hareket eden cisimlerin eşit hızlara sahip olabileceği; üzerindeki net kuvvetin sıfır olduğu bir cismin hareket etmeyeceği ve ivmesi azalan bir cismin hızının da daima azalacağı şeklinde kavram yanılgıları olduğu gösterilmiştir (Zengin, 2018). Kavram yanılgılarının ne kadar dirençli olduğu düşünüldüğünde, öğretmenlerin ortalama hız kapsamında sahip 
olduğu bu tür kavram yanılgılarının, öğrencilerin bu kavramı bilimsel açıdan doğru bir şekilde anlayamamalarının bir diğer nedeni olarak belirtilebilir.

Öğrencilerin kavramsal bilgilerini anlamlandırabilmelerinin diğer bir olumlu etkisinin ise başarı motivasyonlarına yansıdığı ifade edilebilir. Bu durum, BOM Ölçeği'nden elde edilen puanlardan anlaşılmaktadır. Nitekim literatürde çevresi ile fizik kavramlarını bütünleştiren öğrencilerin motivasyonlarının artmasından ve öğrenmelerinin kolaylaşmasından bahsedilmektedir (Butler, 2009; Hırça, 2012). Buna karşılık Sezgin Selçuk, Şahin ve Ün Açıkgöz (2011) fizik dersi kapsamında deney grubundaki üniversite öğrencilerine uyguladıkları soru sorma, özetleme, grafik düzenleyiciler gibi stratejilerin kontrol grubundaki öğrencilerden, başarı motivasyonu anlamında istatistiksel bir fark yaratmadığını tespit etmiştirler. Güngör, Eryılmaz ve Fakığlu (2007) ise üniversite birinci sınıf öğrencileri ile fizik dersi kapsamında yürüttükleri çalışma sonucunda, öğrencilerin fizik başarılarının yükseltilmesi için başarı motivasyonlarına odaklanılmasının önemini ortaya çıkarmıştırlar. Yapılan çalışmada, öğrencilerin başarı motivasyonlarının yükselmesi ile mekanik kavramlarını anlamlandırmaları, bu sonucu destekler niteliktedir.

Çalışmada araştırılan dört kavram, yapılan uygulamalar sonucunda günlük yaşam ile daha anlamlı bir şekilde ilişkilendirilirken ortalama hız kavramı için bu durum geçerli değildir. Ayrıca ortalama hız kavramı, gerçekleştirilen öğretim sonucunda öğrencilerin ileri sürdüğü GYïÖ'nün, GYIOÖ'den düşük kaldığı tek kavramdır. Bu durumda, öğrencilerin ortalama hız kavramını anlamlandırmalarının sınırlı olduğu ortaya çıkmaktadır (Motlhabane, 2016). Anlamlı öğrenme birçok değişken içeren bir süreç olduğundan öğrencilerin fiziksel olgularla ilgili dirençli düşünce yapılarının kısa süreli çalışmalarla değişiminin sağlanması her zaman mümkün olmayabilir (Finegold \& Gorsky, 1988). Yapılan çalışmanın öğretim programının yoğunluğu nedeniyle iki haftalık bir süreci kapsadığ düşünüldüğünde, bu sonuç araştırmanın bir sınırlılığı olarak ortaya çıkmaktadır. Bu nedenle, ortalama hız ve ortalama sürat kavramlarının öğretiminde öğrencilerin bu kavramları daha iyi anlamasını, ayırt etmesini ve günlük yaşamla ilişkilendirebilmesini sağlayacak şekilde, farklı ya da ilave materyal, teknik vb. kullanımı gerektiği düşünülmektedir. Gelecekte yapılacak araştırmalarda, bu problem durumuna odaklanılması önerilebilir. Ayrıca, öğrencilerin ortalama hız, yer değiştirme gibi kavramlar hakkında yanlış yanıtlar vermelerinin bir nedeni olarak sayılabilecek vektör kavramının ayrıntılı bir şekilde ele alınması; gerek lise gerekse üniversite öğrencilerine vektör kavramının daha etkili bir şekilde öğretilmesi gerektiği düşünülmektedir. Gelecekte yapılacak çalışmalarda vektör kavramıyla ilgili özel etkinlikler geliştirilmesi ise yapılan çalışma sonucunda verilebilecek bir diğer öneridir.

Son olarak, çalışmada kullanılan İki Dünya Kuramsal Çerçevesi’nin sınıf öğretmenliği öğrencileri için diğer fizik konularının öğretiminde de kullanılabileceği düşünülmektedir. Aynı yaklaşımın öğretim için ayrılan sürenin sınırlı olduğu diğer fen konularının öğretiminde de kullanılabileceği belirtilebilir. Kullanılan yaklaşımın, ileride temel fen kavramlarının öğretimini gerçekleştirecek öğretmen adaylarının daha iyi günlük yaşam ilişkileri kurmalarını ve daha yüksek öğrenme motivasyonu sağlaması açısından etkili olduğu söylenebilir. Bu kapsamda, öğretim yapacak kişiler tarafından günlük yaşam ile doğrudan ilgili, konuya uygun örnek olaylar geliştirilmesi önerilmektedir.

\section{KAYNAKÇA}

Aluçdibi, F. (2010). Ortaögretim ögrencilerinin biyoloji dersi motivasyon düzeylerine biyoloji öğretmenlerinin sinıf yönetimi profillerinin etkisinin değerlendirilmesi. Yayımlanmamış yüksek lisans tezi, Gazi Üniversitesi, Ankara.

Anggoro, S., Widodo, A., \& Suhandi, A. (2017). Pre-service elementary teachers understanding on force and motion. International Conference on Mathematics and Science Education (ICMScE), $895,1-7$.

Atabek-Yiğit, E., Y1lmazlar, M., \& Çetin, E. (2016). Investigation of classroom teacher candidates' cognitive structures on some basic science concepts. European Journal of Educational Studies, 1(4), 33-57.

Atasoy, S., Küçük, M., \& Akdeniz, A.R. (2011). Remedying science student teachers' misconceptions of force and motion using worksheets based on constructivist learning theory. Energy Education Science and Technology Part B: Social and Educational Studies, 3(4), 519-534. 
Ateş, S. (2008). Mekanik konularındaki kavramları anlama düzeyi ve problem çözme becerilerine cinsiyetin etkisi. Eğitim ve Bilim, 33(148), 3-12.

Ayvacı, H. Ş. (2017). Kuvvet ve hareket. M. F. Taşer \& M. Orbay (Eds.), Genel Fizik-I içinde (ss. 141192). Ankara: Pegem Akademi.

Ayvacı, H. Ş., Bebek, G., Özbek, D., \& Yamak, S. (2015). 2013 yılında revize edilen fizik dersi öğretim programı'nın temel düzeydeki uygulamalarının fizik öğretmenleri tarafindan değerlendirilmesi. Journal of Instructional Technologies \& Teacher Education, 4(3), 35-45.

Balkan Kıyıcı, F., \& Aydoğdu, M. (2011). Fen bilgisi öğretmen adaylarının günlük yaşamları ile bilimsel bilgileri ilişkilendirebilme düzeylerinin belirlenmesi. Necatibey Eğitim Fakültesi Elektronik Fen ve Matematik Ë̆itimi Dergisi (EFMED), 5(1), 43-61.

Bani-Salameh, H. N. (2017). How persistent are the misconceptions about force and motion held by college students?. Physics Education, 52, 1-7.

Bayraktar, Ş. (2009). Misconceptions of turkish pre-service teachers about force and motion. International Journal of Science and Mathematics Education, 7, 273-291.

Budak, M. (2011). Öğrencilerin bilimsel düşünme evreleri ile hareket kuvveti gerektirir kavram yanılgısı düzeyleri arasındaki ilişkinin incelenmesi. Yayımlanmamış yüksek lisans tezi, Abant İzzet Baysal Üniversitesi, Bolu.

Butler, M. B. (2009). Motivating young students to be successful in science: keeping it real, relevant and rigorous. National geographic, July 2009.

Büyüköztürk, Ş. (2010). Sosyal bilimler için veri analizi el kitabı (11. Baskı). Ankara: PegemA Yayınc1lik.

Büyüköztürk, Ş., Kılıç Çakmak, E., Akgün, Ö. E., Karadeniz, Ş., \& Demirel, F. (2010). Bilimsel araştırma yöntemleri (6. Baskı). Ankara: PegemA Yayıncılık.

Chang, H.-P., Chen, J.-Y., Guo, C.-J., Chen, C.-C., Chang, C.-Y., Lin, S.-H., et al. (2007). Investigating primary and secondary students' learning of physics concepts in Taiwan. International Journal of Science Education, 29(4), 465-482.

Erdem, A. R. (1997). İçerik kuramları ve eğitim yönetimine katkıları. Pamukkale Üniversitesi Eğitim Fakültesi Dergisi, 3(3), 68-76.

Ery1lmaz, A. (2002). Effects of conceptual assignments and conceptual change discussions on students' misconceptions and achievement regarding force and motion. Journal of Research in Science Teaching, 39(10), 1001-1015.

Eryılmaz, A., \& Tatl1, A. (2000). Odtü öğrencilerinin mekanik konusundaki kavram yanılgıları. Hacettepe Üniversitesi Ĕ̈itim Fakültesi Dergisi, 18, 93-98.

Fadaei, A. S., \& Mora, C. (2015). An investigation about misconceptions in force and motion in high school. US-China Education Review A, 5(1), 38-45.

Finegold, M., \& Gorsky, P. (1988). Learning about forces: simulating the outcomes of pupils' misconceptions. Instructional Science, 17, 251-261.

Giancoli, D. C. (1998). Physics - principles with applications $\left(5^{\text {th }}\right.$ Ed.). New Jersey: Prentice Hall.

Gutwill-Wise, J.P. (2001). The impact of active and context-based learning in introductory chemistry courses: an early evaluation of the modular approach. Journal of Chemical Education, 78(5), 684-690.

Gümüş, S. (2017). Hareket bilgisi (kinematik). M. F. Taşer \& M. Orbay (Eds.), Genel Fizik-I içinde (ss. 69-140). Ankara: PegemA Yayınc1lik.

Güngör, A. A., Eryılmaz, A., \& Fakığlu, T. (2007). The relationship of freshmen's physics achievement and their related affective characteristics. Journal of Research in Science Teaching, 44(8), 1036-1056.

Hırça, N. (2012). Bağlam temelli öğrenme yaklaşımına uygun etkinliklerin öğrencilerin fizik konularını anlamasına ve fizik dersine karşı tutumuna etkisi. Mustafa Kemal Üniversitesi Sosyal Bilimler Enstitüsü Dergisi, 9(17), 313-325. 
Jimoyiannis, A., \& Komis, V. (2003). Investigating Greek students' ideas about forces and motion. Research in Science Education, 33, 375-392.

Jones, A. T. (1983). Investigation of students' understanding of speed, velocity and acceleration. Research in Science Education, 13, 95-104.

Karamustafaoğlu, O. (2018). Are mass and weight the same?' activity developed based on quantum learning model and teachers' opinions. International Journal on Lifelong Education and Leadership, 4(1), 36-40.

Karaoğlu, B. (2013). Üniversiteler için fizik (3. Baskı). Ankara: Seçkin Yayıncılık.

Kikas, E. (2004). Teachers' conceptions and misconceptions concerning three natural phenomena. Journal of Research in Science Teaching, 41(5), 432-448.

Martin, A. J. (2001). The Student motivation scale: A tool for measuring and enhancing motivation. Australian Journal of Guidance and Counselling, 11, 1-20.

Martín-Blas, T., Seidel, L., \& Serrano-Fernández, A. (2010). Enhancing force concept inventory diagnostics to identify dominant misconceptions in firstyear engineering physics. European Journal of Engineering Education, 35(6), 597-606.

MEB. (2018). Ortaöğretim fizik dersi $(9,10,11$ ve 12. sinıflar) öğretim programı. Ankara.

Miles, M. B., \& Huberman, A. M. (1994). Qualitative data analysis an expanded sourcebook ( $2^{\text {nd }}$ Ed.). California: Sage Publications.

Motlhabane, A. (2016). Learner's alternative and misconceptions in physics: A phenomenographic study. Journal of Baltic Science Education, 15(4), 424-440.

Nik Daud, N. S., Abd Karim, M. M., Wan Hassan, S. W. N., \& Abdul Rahman, N. (2015). Misconception and difficulties in introductory physics among high school and university students: An overview in mechanics. Journal of Science, Mathematics and Technology, 2(1), 34 47.

Özmen, H. (2003). Kimya öğretmen adaylarının asit ve baz kavramlarılla ilgili bilgilerini günlük olaylarla ilişkilendirebilme düzeyleri. Kastamonu Eğitim Dergisi, 11(2), 317-324.

Poutot, G., \& Blandin, B. (2015). Exploration of students' misconceptions in mechanics using the FCI. American Journal of Educational Research, 3(2), 116-120.

Rodríguez-Velázquez, S. (2013). Development of an electrochemistry teaching sequence using a phenomenographic approach. Unpublished PhD Thesis, Graduate Faculty of North Carolina State University, Raleigh, North Carolina, USA.

Rosa, E. D. D., \& Bernardo, A. B. I. (2013). Are two achievement goals better than one? Filipino students' achievement goals, deep learning strategies and affect. Learning and Individual Differences, 27, 97-101.

Ruthven, K., Laborde, C., Leach, J., \& Tiberghien, A. (2009). Design tools in didactical research: instrumenting the epistemological and cognitive aspects of the design of teaching sequences. Educational Researcher, 38(5), 329-342.

Semerci, Ç. (2010). Başarı odaklı motivasyon (bom) ölçeği'nin geliştirilmesi. e-Journal of New World Sciences Academy, 5(4), 2123-2133.

Serway, R. A., \& Beichner, R. J. (2002). Fen ve mühendislik için fizik 1 (Çev. Ed. K. Çolakoğlu). Ankara: Palme Yayıncilık.

Sezgin Selçuk, G., Sahin, M., \& Ün Açıkgöz, K. (2011). The effects of learning strategy instruction on achievement, attitude, and achievement motivation in a physics course. Research in Science Education, 41, 39-62.

Soudani, M., Sivade, A., Cros, D., \& Médimagh, M. S. (2000). Transferring knowledge from the classroom to the real world: redox concepts. School Science Review, 82(298), 65-72.

Stylos, G., Evangelakis, G. A., \& Kotsis, K. T. (2008). Misconceptions on classical mechanics by freshman university students: A case study in a physics department in Greece. Themes in Science and Technology Education, 1(2), 157-177. 
Şimşek, D. (2018). Fen bilgisi öğretmeni adaylarının kuvvet ve hareket konularındaki kavram yanılgıları. Yayımlanmamış yüksek lisans tezi, Atatürk Üniversitesi, Erzurum.

Tebabal, A., \& Kahssay, G. (2011). The effects of student-centered approach in improving students' graphical interpretation skills and conceptual understanding of kinematical motion. LatinAmerican Journal of Physics Education, 5(2), 374-381.

Tiberghien, A. (2000). Designing teaching situations in the secondary school. In R. Millar, J. Leach, \& J. Osborne (Eds.), Improving science education: The contribution of research (pp. 27-47). Buckingham, UK: Open University Press.

Trowbridge, D. E., \& McDermott, L. C. (1980). Investigation of student understanding of the concept of velocity in one dimension. American Journal of Physics, 48(12), 1020-1028.

Tural, G. (2017). Investigation of students and teacher candidates to establish the relationship between simple harmonic motion and uniform circular motion. Inönü University Journal of the Faculty of Education, 18(3), 269-280.

Türker, F. (2005). Developing a three-tier test to assess high school students' misconceptions concerning force and motion. Yayımlanmamış yüksek lisans tezi, Orta Doğu Teknik Üniversitesi, Fen Bilimleri Enstitüsü, Ankara.

Ülgen, G. (1994). Ĕgitim psikolojisi: Kavramlar, ilkeler, yöntemler, kuramlar ve uygulamalar, Ankara: Lazer Ofset Matbaa.

Watters, J. J., \& Ginns, I. S. (2000). Developing motivation to teach elementary science: Effect of collaborative and authentic learning practices in preservice education. Journal of Science Teacher Education, 11(4), 277-313.

Whitelegg, E., \& Parry, M. (1999). Real-life contexts for learning physics: meanings, issues and practice. Physics Education, 34, 68-72.

Yadigaroğlu, M., \& Demircioğlu, G. (2012). Kimya öğretmen adaylarının kimya bilgilerini günlük hayattaki olaylarla ilişkilendirebilme düzeyleri. Journal of Research in Education and Teaching, $1(2), 165-171$.

Yavuz, A., \& Fide, H. H. (2010). Sınıf öğretmenliği genel fizik dersine farklı bir yaklaşım: iki dünya kuramsal çerçevesi. e-Journal of New World Sciences Academy Education Sciences, 5(3), 13161327.

Yıldırım, A., \& Şimşek, H. (2008). Sosyal bilimlerde nitel araştırma yöntemleri (6. Baskı). Ankara: Seçkin Yayıncilık.

Yıldırım, N., \& Birinci Konur, K. (2014). Fen bilgisi öğretmen adaylarının kimya kavramlarını günlük hayatla ilişkilendirebilmelerine yönelik gelişimsel bir araştırma. The Journal of Academic Social Science Studies, 30, 305-323.

YÖK.(1998).Sınıf öğretmenliği lisans program1. https://www.yok.gov.tr/Documents/Yayinlar/Yayinlarimiz/egitim-fakultesi-ogretmenyetistirme-lisans-programlari-mart-1998.pdf (Erişim Tarihi: 10/10/2019)

YÖK.(2007).Sınıf öğretmenliği lisans programı. https://www.yok.gov.tr/Documents/Yayinlar/Yayinlarimiz/egitim-fakultesi-ogretmenyetistirme-lisans-programlari.pdf (Erişim Tarihi: 10/10/2019)

YÖK.(2018).Sınıf öğretmenliği lisans programı. https://www.yok.gov.tr/kurumsal/idaribirimler/egitim-ogretim-dairesi/yeni-ogretmen-yetistirme-lisans-programlari (Erişim Tarihi: $10 / 10 / 2019)$

Zengin, Y. (2018). 9. sinuf kuvvet ve hareket konusu ile ilgili 3 aşamalı kavram testi geliştirilmesi ve kavramsal değişim metinlerinin oluşturulması. Yayımlanmamış yüksek lisans tezi, Necmettin Erbakan Üniversitesi, Konya. 